\title{
Heterosis and Specific Combining Ability in Sweet Corn and Its Correlation with Genetic Similarity of Inbred Lines
}

\author{
Purwito Djoko Yuwono ${ }^{1}$, Rudi Hari Murti ${ }^{1} \&$ Panjisakti Basunanda ${ }^{1}$ \\ ${ }^{1}$ Faculty of Agriculture, Universitas Gadjah Mada, Yogyakarta, Indonesia \\ Correspondence: Rudi Hari Murti, Faculty of Agriculture, Gadjah Mada University, Jl. Flora, Bulaksumur, \\ Yogyakarta, Indonesia. Tel: 62-274-551-228. E-mail: rhmurti@ugm.ac.id
}

Received: July 1, 2016

doi:10.5539/jas.v9n3p245
Accepted: December 28, $2016 \quad$ Online Published: February 15, 2017

URL: http://dx.doi.org/10.5539/jas.v9n3p245

\begin{abstract}
The heterosis phenomena has been exploited in hybrid maize field production. Theoretically, heterosis was depending on genetic distance of inbred lines. Meanwhile, different from field corn breeding, sweet corn does not have well defined heterotic group. The objective of this study was to determine genetic similarity (GS) of eight selected inbred lines of sweet corn based on morphological traits and its correlation with specific combining ability (SCA) and heterosis. The eight inbred lines were characterized and crossed in full diallel design. Then, the lines, F1 and its reciprocal, were evaluated by using the Randomized Complete Block Design in three replications. The result showed positive heterosis and SCA effect in most of the hybrids which indicated the heterosis effect in the hybrids performance. Based on the morphological traits, the genetic similarity between the inbred lines was $62.2-82.4 \%$. The inbred lines with $70 \%$ similarity coefficient were grouped into three. There was significant correlation between the genetic similarity and heterosis in all traits, except in the plant height. Meanwhile, only SCA of days to maturity and TSS showed significant correlation to genetic similarity. This indicated the usefullness of genetic similarity to identify the potential inbred lines for parental hybrid.
\end{abstract}

Keywords: genetic similarity, diallel analysis, SCA, heterosis, correlation sweet corn

\section{Introduction}

In Indonesia, sweet corn has been cultivated on a relatively small acreage, e.g. 3,838,015 ha. On the other hand, the production is recently increasing, mainly due to its high economic return (Rifianto et al., 2013). Initiated in 2010, the sweet corn breeding in Agro Nusantara Prima (ANP) Ltd, Yogyakarta produced inbred lines that could be evaluated as the parent of sweet corn hybrid.

Most sweet corn hybrids are based on the recessive $s u$ gene which alters normal starch synthesis that results in accumulation of phytoglycogen rather than starch. This provides sweet corn with characteristic smooth texture and creaminess (Marshall \& Tracy, 2003). Although the sul gene is one of the earliest genes genetically well characterized (Marshall \& Tracy, 2003; Tracy et al., 2006), and various research identified genetic variation among germplasm containing the sul gene could not be reliably related to heterotic patterns (Revilla et al., 2005; Bered et al., 2005), such as those important in field corn breeding (Hallauer et al., 2010). The narrowness of present genetic variability of $s u$ sweet corn is the result of the fact that most of today's sweet corn germplasm originates from only few open-pollinated varieties Golden Bantam, Country Gentleman, and Stowell's Evergreen (Gerdes \& Tracy, 1994).

Genetic diversity in relation to hybrid performance has been studied extensively in maize such as Kiula et al. (2008) that reported the correlation between genetic similarity, hybrid performance and SCA in predicting hybrid performance. While Legesse et al. (2008) found any correlation of genetic distance with hybrid performance (heterosis). Similar result was reported by Suwarno et al. (2014).

Only a little of information about the genetic diversity and heterotic models in sweet corn germplasm is available. This experiment also faced the same problem and strived to explore the probability by using the genetic similarity in predicting the hybrid performance. Determining performances of inbred lines as potential hybrid parents through field experiments and diallel crosses has been widely used in sweet corn breeding programs (Kashiani et al., 2010; Assunacao et al., 2010), since they provide information on the type of the predominant 
gene action, assess heterotic potential and general and specific combining ability of genotypes (Hallauer et al., 2010).

The aims of this study comprised the assessment of Specific Combining Ability (SCA), heterosis, genetic similarity of eight sweet corn inbred lines based on the morphological traits and the correlation between SCA and heterosis and genetic similarity. The concurrence between data could contribute to the efficiency of the sweet corn breeding programs.

\section{Materials and Methods}

The experiment was conducted in Bantul, Yogyakarta, Indonesia. The eight inbred lines of sweet corn (Table 1) were grown in Randomized Complete Block Design in three replications. Optimum growing conditions were applied. Prior to sowing, 2,000 kg/ha organic manure was added in the soil; $150 \mathrm{~kg} / \mathrm{ha}$ nitrogen and $150 \mathrm{~kg} / \mathrm{ha}$ nitrogen NPK was side-dressed at 5 and 21 days after planting; $100 \mathrm{~kg} / \mathrm{ha}$ phosphate $\left(\mathrm{P}_{2} \mathrm{O}_{5}\right)$ and potassium $(\mathrm{K})$ were applied at 21 and 37 days after planting, respevtively.

Table 1. List of sweet corn inbred lines

\begin{tabular}{ll}
\hline Name & Inbred lines identity \\
\hline ANP-A & AN 6/15-8-6-1/2-1/4-1/1-1/5 \\
ANP-B & AN 4/5-10-8-1/4-1/3-1/1-1/1 \\
ANP-C & AN 6/6-9-17-1/2-1/1-1/2-1/6 \\
ANP-H & AN $13 / 1-7-20-1 / 1-1 / 1-1 / 3-1 / 1$ \\
ANP-K & AN 4/5-10-26-1/1-1/2-1/3-1/4 \\
ANP-R & AN 7/4-4-29-1/1-1/1-1/2-1/1 \\
ANP-S & AN 6/6-9-17-1/4-1/1-1/2-1/4 \\
ANP-T & AN 7/4/3-5/1-2/2-1/3-1/4-2/3 \\
\hline
\end{tabular}

Recorded data of the eight parental inbred lines consisted of days to anthesis and days to silking (days), plant height $(\mathrm{cm})$, ear height $(\mathrm{cm})$, ear diameter $(\mathrm{cm})$, ear length $(\mathrm{cm})$, number of rows per ear, number of kernels per row, ear weight (g) and total soluble solids ( ${ }^{\circ}$ brix).

In the second experiment, diallel crosses was made for the eight inbred lines by using the Griffing Method I. The seeds of each combination of crosses and reciprocal were considered as hybrid, which were $56 \mathrm{~F}_{1}$ hybrids in total. All hybrids and parental were evaluated by using RCBD in three replicates. Each replication consisted of 64 experimental units, each consisted of eight plants with spaces between and within rows of $80 \mathrm{~cm}$ and $25 \mathrm{~cm}$, respectively.

Data of 10 characters of eight inbred lines were used to determine morphological genetic similarity between the inbred lines by applying the Minitab ${ }^{\circledR}$ software for cluster analysis. On the other hand, diallel analysis was applied to hybrid data for estimating the specific combining ability. Diallel analysis used SAS 9.3 for Windows ${ }^{\circledR}$ 64 bit with the procedure PROC SQ1 macro program as described in Zhang et al. (2005). Best parent heterosis of hybrids was calculated based on the best parent as described by Fehr (1987), as follows:

$$
\text { Heterosis best parent }=\frac{\mathrm{F} 1-\mathrm{BP}}{\mathrm{BP}} \times 100 \%
$$

Where, BP is the mean value of the best parent.

\section{Results and Discussion}

The analysis of varians showed that the SCA variance were significant for all of the characters (Table 2). It indicated that all characters were controlled by non-additive genes. The reciprocal cross was also significantly different. Similar results have been reported by Iriany et al. (2011) for ear weight and ear length; Beyene et al. (2011) for grain yield, days to anthesis and plant height; Olakojo and Olaoye (2005) for ear weight, plant height, days to anthesis and days to silking; Malik et al. (2004) for plant height and days to anthesis.

The significant SCA effect indicated the significant deviation of specific crosses from the average performance of their parents (Hallauer et al., 2010). SCA values of the days to anthesis and days to silking, and plant height were significantly negative. It implied hybrids with early maturity and shorter plant and indicated shorter duration of sweet corn production. In B $\times \mathrm{C}$ hybrid, the best SCA $(-1.46)$ values were the days to anthesis and days to silking. Whereas in $\mathrm{T} \times \mathrm{K}$ hybrid, the best SCA was the plant height (-24.11) (Table 3). The $\mathrm{B} \times \mathrm{C}$ and $\mathrm{T}$ 
$\times \mathrm{K}$ were promising hybrids, each for its early maturity and short plant, respectively. The best SCA for ear length and weight (Table 4) (2.16 and 38.72, respectively) were in $\mathrm{K} \times \mathrm{T}$ hybrid; while in $\mathrm{R} \times \mathrm{H}$ hybrid, the best SCA was the TSS (1.23). Vasal et al. (1992) suggests that positive SCA effects indicate that lines are in opposite heterotic groups while negative SCA effects indicate that lines are in the same heterotic group.

Heterosis was the appearance of hybrid superiority compared with the two parents (Fehr, 1987). The breeder strive to obtain the shorter characters of days to anthesis, days to silking and plant height as indicated in the negative heterosis value of the hybrid. On the other hand, high heterosis values of economical characters, such as ear length, ear weight and TSS, were very much desirable. The result showed that the best heterosis for days to anthesis (Table 5) was $-7.40 \%$ in $\mathrm{T} \times \mathrm{B}$ hybrid. This finding implied that the earliest male flower matrity was in TxB hybrid, which was $7.40 \%$ faster. This indicated the shorter of days to silking (Table 5) than its best parental (C).

Table 2. Analysis of variance diallel

\begin{tabular}{|c|c|c|c|c|c|c|c|}
\hline \multirow{2}{*}{ Source of variance } & \multirow{2}{*}{$d f$} & \multicolumn{6}{|c|}{ Mean square } \\
\hline & & DA & $\mathrm{DS}$ & $\mathrm{PH}$ & EL & EW & TSS \\
\hline Replication & 2 & $3.32 * *$ & $3.32 * *$ & $51.72^{\mathrm{ns}}$ & $1.41^{\mathrm{ns}}$ & $928.46^{\mathrm{ns}}$ & $31.73^{* *}$ \\
\hline Hybrids & 55 & $5.49 * *$ & $5.49 * *$ & $976.48 * *$ & $8.45^{* *}$ & $3884.51 * *$ & $3.65 * *$ \\
\hline $\mathrm{SCA}$ & 28 & $4.32 * *$ & $4.32 * *$ & $879.91 * *$ & $8.24 * *$ & $6057.50 * *$ & $3.41 * *$ \\
\hline Reciprocal & 28 & $5.21 * *$ & $5.21 * *$ & $798.33^{* *}$ & $7.20 * *$ & $2266.80^{* *}$ & $3.55 * *$ \\
\hline Error & 126 & 0.43 & 0.43 & 193.15 & 0.52 & 518.01 & 1.74 \\
\hline $\mathrm{CV}(\%)$ & & 1.61 & 1.53 & $6.77^{--1}$ & 4.01 & 13.34 & 9.48 \\
\hline
\end{tabular}

Note. DA: days to anthesis; DS: days to silking; PH: plant height; EL: ear length; EW: ear weight; TSS: total soluble solids; ns: not significant; * and **: significant at P-value $\leq 0.05$ and P-value $\leq 0.01$, respectively; CV: coefficient of variance.

Tabel 3. SCA estimation of 56 hybrids for days to anthesis, days to silking and plant height

\begin{tabular}{|c|c|c|c|c|c|c|c|c|}
\hline Hybrid & $\mathrm{A}$ & B & $\mathrm{C}$ & $\mathrm{H}$ & $\mathrm{K}$ & $\mathrm{R}$ & $\mathrm{S}$ & $\mathrm{T}$ \\
\hline \multirow[t]{3}{*}{$\mathrm{A}$} & & $2.45^{* *}$ & $-0.53^{*}$ & 0.27 & -0.03 & 0.02 & $-0.65^{* *}$ & $-0.92^{* *}$ \\
\hline & & $2.45^{* *}$ & $-0.53^{*}$ & 0.27 & -0.03 & 0.02 & $-0.65^{* *}$ & $-0.92^{* *}$ \\
\hline & & -6.13 & 0.90 & 8.14 & 7.40 & -9.67 & 5.12 & $20.32^{* *}$ \\
\hline \multirow[t]{3}{*}{$\mathrm{B}$} & $3.33^{* *}$ & & $-1.46^{* *}$ & $-1.17^{*--}$ & -0.13 & $0.08^{--}$ & $-1.26^{* 6-}$ & -0.36 \\
\hline & $3.33^{* *}$ & & $-1.46^{* *}$ & $-1.17^{* *}$ & -0.13 & 0.08 & $-1.26^{* *}$ & -0.36 \\
\hline & -10.22 & & 7.79 & 6.03 & $15.12^{* *}$ & $12.11^{*}$ & 8.45 & -2.85 \\
\hline \multirow[t]{3}{*}{$\mathrm{C}$} & $0.67^{*-}$ & $0.67^{*-}$ & & $1.02^{* * *-}$ & -0.28 & $-0.73^{\text {x }}$ & 0.27 & $0.49^{*}$ \\
\hline & $0.67^{*}$ & $0.67^{*}$ & & $1.02^{* *}$ & -0.28 & $-0.73^{* *}$ & 0.27 & $0.49^{*}$ \\
\hline & -1.72 & -9.00 & & $16.12^{* *}$ & 9.43 & -1.19 & 0.04 & -9.31 \\
\hline \multirow[t]{3}{*}{$\mathrm{H}$} & -0.17 & $-1.33^{\text {*F- }}$ & -0.17 & & 0.18 & $0.56^{7-}$ & 0.06 & -0.38 \\
\hline & -0.17 & $-1.33^{* *}$ & -0.17 & & 0.18 & $0.56^{*}$ & 0.06 & -0.38 \\
\hline & 3.39 & $13.00^{*}$ & -6.78 & & -5.94 & 2.88 & -6.22 & $-12.02^{*}$ \\
\hline \multirow[t]{3}{*}{$\mathrm{K}$} & $-1.00^{* * 7^{-}}$ & $0.50^{--}$ & $0.67^{*-}$ & $1.17^{* *-}$ & & $-0.57^{*-}$ & 0.43 & 0.16 \\
\hline & $-1.00^{* *}$ & 0.50 & $0.67^{*}$ & $1.17^{* *}$ & & $-0.57^{*}$ & 0.43 & 0.16 \\
\hline & 6.83 & $13.50^{*}$ & $17.95^{* *}$ & $-20.33^{* *}$ & & $-12.69^{*}$ & -4.08 & 1.12 \\
\hline \multirow[t]{3}{*}{$\mathrm{R}$} & -0.50 & -0.17 & -0.33 & $1.00^{* *--}$ & 0.00 & & $0.97^{* *-}$ & 0.37 \\
\hline & -0.50 & -0.17 & -0.33 & $1.00^{* *}$ & 0.00 & & $0.97^{* *}$ & 0.37 \\
\hline & $11.61^{*}$ & 6.89 & 1.94 & 5.56 & 0.28 & & $-10.69^{*}$ & $15.62^{* *}$ \\
\hline \multirow[t]{3}{*}{$\mathrm{S}$} & -0.17 & $-1.17^{* *-}$ & $1.00^{* *-}$ & -0.50 & $0.67^{*-}$ & 0.00 & & 0.20 \\
\hline & -0.17 & $-1.17^{* *}$ & $1.00^{* *}$ & -0.50 & $0.67^{*}$ & 0.00 & & 0.20 \\
\hline & $19.28^{* *}$ & $25.89^{* *}$ & -1.72 & -9.33 & 1.11 & -4.56 & & -3.71 \\
\hline \multirow[t]{3}{*}{$\mathrm{T}$} & 0.17 & 0.00 & 0.17 & $-0.67^{*}$ & -0.33 & $-1.00^{* *}$ & $1.17^{* *}$ & \\
\hline & 0.17 & 0.00 & 0.17 & $-0.67^{*}$ & -0.33 & $-1.00^{* *}$ & $1.17^{* *}$ & \\
\hline & $-15.28^{* *}$ & 3.17 & -6.83 & 0.11 & $-24.11^{* *}$ & -3.56 & 9.56 & \\
\hline
\end{tabular}

Note. For each crosses, first row: days to anthesis, second row: days to silking; third row: plant height; * and **: significant at $\mathrm{P}$-value $\leq 0.05$ and $\mathrm{P}$-value $\leq 0.01$, respectively. 
The heterosis of plant height in $\mathrm{R} \times \mathrm{S}$ hybrid of $-8.80 \%$ was the lowest (Table 5 ). The plant height of $\mathrm{R} \times \mathrm{S}$ hybrid was $8.80 \%$ shorter than its best parent $(\mathrm{S})$. The best heterosis of $\mathrm{T} \times \mathrm{H}$ hybrid (Table 6) was the ear length i.e. $41.98 \%(21.10 \mathrm{~cm})$, indicating that $\mathrm{T} \times \mathrm{H}$ height was shorter than the best parental $(\mathrm{S})$. While in $\mathrm{B} \times \mathrm{S}$ hybrid (Table 6), the best heterosis was the ear weight i.e. $157.12 \%(221.33 \mathrm{~g})$.

Most hybrids showed positive heterosis that indicated the existence of heterosis effect in the hybrids performance. Among all the traits, the highest heterosis (157.12\%) was the ear weight, which was in accordance with other reports in maize (Saleh et al., 2002; Legesse et al., 2008). The heterosis value of ear weight was classified in the type of over-dominant genes action (Hallauer et al., 2010).

Tabel 4. SCA estimation of 56 hybrids for ear length, ear weight and total soluble solids

\begin{tabular}{|c|c|c|c|c|c|c|c|c|}
\hline Hybrid & A & B & $\mathrm{C}$ & $\mathrm{H}$ & $\mathrm{K}$ & $\mathrm{R}$ & $\mathrm{S}$ & $\mathrm{T}$ \\
\hline \multirow[t]{3}{*}{$\mathrm{A}$} & & 0.50 & $0.73^{* *}$ & 0.47 & $0.55^{*}$ & $-1.31^{* *}$ & 0.46 & 0.28 \\
\hline & & 1.90 & $29.72^{* *}$ & 5.82 & 8.70 & -8.01 & 11.86 & $25.75^{* *}$ \\
\hline & & -0.01 & -0.31 & 0.18 & 0.57 & 0.19 & 0.25 & 0.08 \\
\hline \multirow[t]{3}{*}{ B } & $-1.78^{\text {***- }}$ & & $0.93^{\text {** }}$ & 0.27 & $0.58^{*-}$ & -0.15 & 0.36 & $-0.56^{*-}$ \\
\hline & $-19.78^{*}$ & & 5.89 & $22.26^{* *}$ & $25.59^{* *}$ & $27.49^{* *}$ & $23.86^{* *}$ & -9.36 \\
\hline & $-2.08^{* *}$ & & -0.22 & -0.32 & -0.04 & -0.46 & -0.12 & 0.54 \\
\hline \multirow[t]{3}{*}{$\mathrm{C}$} & 0.42 & -0.20 & & 0.43 & -0.32 & $1.50^{* 7^{-}}$ & 0.28 & $-1.46^{* 6}$ \\
\hline & 11.89 & -4.44 & & $23.63^{* *}$ & 0.29 & $19.80^{*}$ & $27.50^{* *}$ & $-35.93^{* *}$ \\
\hline & -0.38 & 0.57 & & 0.11 & 0.51 & 0.81 & 0.73 & $-0.97^{*}$ \\
\hline \multirow[t]{3}{*}{$\mathrm{H}$} & $0.90^{\text {*F- }}$ & 0.29 & $0.81^{* *-1}$ & & $-0.58^{*-}$ & 0.37 & $-0.95^{\text {*a }}$ & $1.62^{\text {*n- }}$ \\
\hline & 15.33 & -10.94 & $35.83^{* *}$ & & 5.56 & -13.44 & -10.07 & -0.95 \\
\hline & 0.58 & 0.21 & 0.31 & & 0.11 & $1.03^{*}$ & 0.02 & $1.10^{*}$ \\
\hline \multirow[t]{3}{*}{$\mathrm{K}$} & $1.25^{\text {sक }}$ & $-1.19^{* *}$ & $2.08^{* *}$ & $-0.93^{* *--}$ & & $-0.87^{\text {*3- }}$ & 0.13 & $2.16^{3 *-}$ \\
\hline & 9.06 & -12.56 & $32.89^{* *}$ & $-30.05^{* *}$ & & $-22.71^{* *}$ & -1.90 & $38.72^{* *}$ \\
\hline & 0.83 & -0.25 & 0.01 & 0.05 & & -0.88 & 0.03 & 0.39 \\
\hline \multirow[t]{3}{*}{$\mathrm{R}$} & $-1.61^{\text {**- }}$ & 0.36 & $-1.46^{* *-}$ & 0.37 & $1.18^{* *-}$ & & $1.16^{* 3}$ & $1.34^{* 3-1}$ \\
\hline & $-28.95^{* *}$ & -0.17 & $-22.55^{*}$ & 8.00 & 11.67 & & 13.33 & $31.45^{* *}$ \\
\hline & $-1.17^{*}$ & -0.46 & -0.71 & $1.23^{*}$ & -0.05 & & 0.90 & 0.38 \\
\hline \multirow[t]{3}{*}{$\mathrm{S}$} & 0.55 & $1.16^{* a-1}$ & $1.40^{\text {*** }}$ & -0.07 & $-0.94^{* *^{*}-}$ & 0.37 & & -0.17 \\
\hline & 6.22 & $29.50^{* *}$ & 17.67 & $-19.78^{*}$ & -1.56 & 5.17 & & 5.48 \\
\hline & -0.10 & -0.51 & 0.25 & -0.48 & 0.22 & 0.54 & & -0.07 \\
\hline \multirow[t]{3}{*}{$\mathrm{T}$} & $0.10^{\circ}$ & $-1.91^{* * *}$ & 0.08 & $-2.26^{* *^{--}}$ & -0.02 & $0.86^{* *}$ & -0.16 & \\
\hline & 2.11 & $-21.39^{*}$ & -14.67 & $-39.00^{* *}$ & $-24.94^{* *}$ & 8.83 & 8.72 & \\
\hline & 0.16 & $1.08^{*}$ & 0.37 & $-1.92^{* *}$ & -0.89 & 0.42 & 0.31 & \\
\hline
\end{tabular}

Note. For each crosses, first row: ear length, second row: ear weight; third row: total soluble solids; * and **: significant at $\mathrm{P}$-value $\leq 0.05$ and $\mathrm{P}$-value $\leq 0.01$, respectively.

Heterosis and SCA are the two most important variables in hybrid studies. Both are estimated following the data of F1 hybrid evaluation. When there are so many F1 combinations, significant resources are allocated for F1 hybrid performance evaluation. In maize, Kiula et al. (2008), Legesse et al. (2008), and Suwarno et al. (2014) found the correlation between genetic similarity and hybrid performance and SCA. The crosses between parental inbred lines that have low similarity will produce $\mathrm{F}_{1}$ hybrid that have a higher heterosis than the lines with high similarity (Iriany et al., 2011). It implied that genetic similarity could be used as predictor of hybrid performance.

Similarity coefficient of B and $\mathrm{S}$ was $63.68 \%$ (Table 7). It was also presented in the hybrid $\mathrm{T} \times \mathrm{B}$ and $\mathrm{C} \times \mathrm{B}$ whose best heterosis was for days to anthesis and days to silking. High heterosis values in the three hybrids were allegedly due to low similarity between parental inbred lines and differences of heterotic groups. Suwarno et al. (2014) explains that the hybrids which resulted from crosses of two inbred lines and different heterotic group will have a high heterosis level.

Cluster analysis was used to classify the inbred lines into several classes by grouping criteria based on the similarity of morphological characteristics (Nisya, 2010). Similarities between lines can be determined by similarity coefficients, whereas the greater value of the coefficient indicates more similarity between lines and 
the other (Mattjik \& Sumertajaya, 2011). Value of $62.28 \%-100 \%$ in the dendrogram (Figure 1) shows the scale based on similarity coefficients. Inbred lines were divided into three groups based on similarity coefficient of $70 \%$ (Figure 1). The group I consisted of lines A, H, K, R, S and T; while group II and III only consisted of lines $\mathrm{B}$ and $\mathrm{C}$, respectively. It implied that $\mathrm{B}$ and $\mathrm{C}$ lines had least similarity to others indicating their highest genetic distance to others.

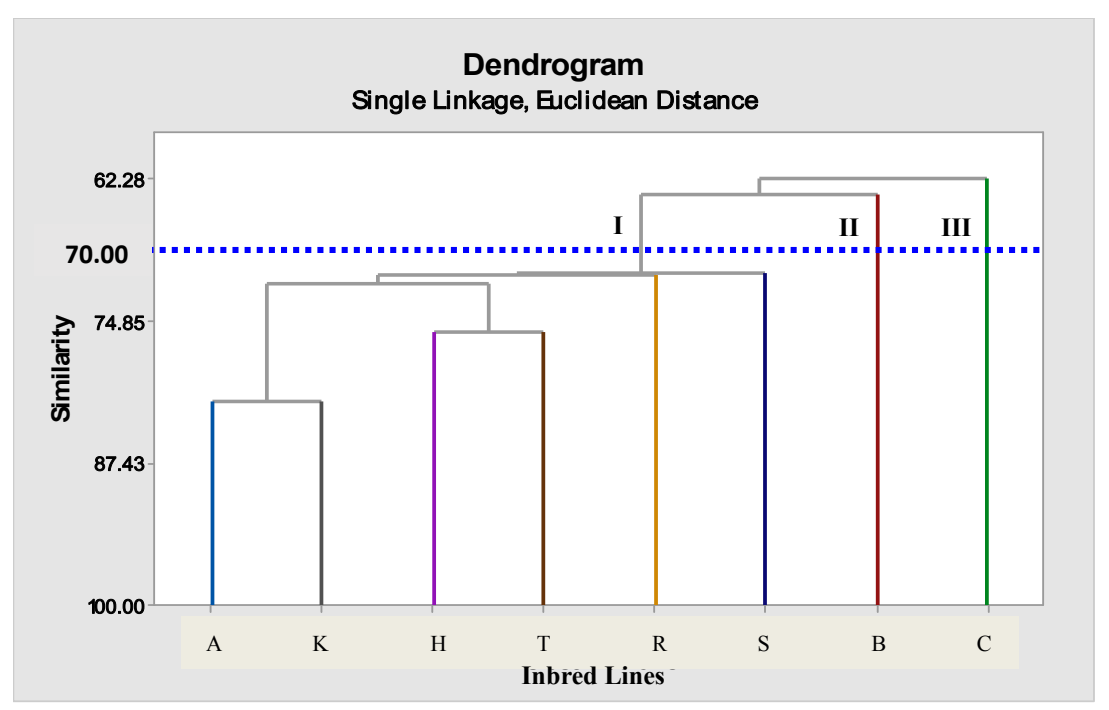

Figure 1. Dendrogram of genetic relationship among 8 sweet corn inbred lines revealed by Euclidean cluster analysis based on six morphological traits

Table 5. Heterosis estimations of 56 hybrids for days to anthesis, days to silking and plant height

\begin{tabular}{|c|c|c|c|c|c|c|c|c|}
\hline Hybrid & $\mathrm{A}$ & B & $\mathrm{C}$ & $\mathrm{H}$ & $\mathrm{K}$ & $\mathrm{R}$ & $S$ & $\mathrm{~T}$ \\
\hline \multirow[t]{3}{*}{ A } & & 18.02 & 1.62 & 2.23 & -1.36 & 1.94 & -1.09 & -0.84 \\
\hline & & 17.18 & 1.55 & 2.38 & -1.57 & 1.59 & -0.78 & -0.79 \\
\hline & & 15.94 & 20.15 & 29.70 & 29.00 & 28.86 & 38.41 & 31.81 \\
\hline \multirow[t]{3}{*}{ B } & 1.35 & & -2.36 & -1.68 & 4.14 & 5.04 & -2.48 & 0.82 \\
\hline & 1.55 & & -2.25 & -1.59 & 3.95 & 4.79 & -2.35 & 0.78 \\
\hline & 28.86 & & 18.09 & 30.58 & 33.88 & 35.28 & 39.86 & 25.49 \\
\hline \multirow[t]{3}{*}{$\mathrm{C}$} & -1.92 & -5.24 & & 4.18 & 1.39 & 0.00 & 4.14 & 0.82 \\
\hline & -1.57 & -5.26 & & 3.97 & 1.58 & -0.01 & 3.95 & 0.78 \\
\hline & 22.33 & 28.45 & & 20.65 & 28.84 & 20.46 & 14.84 & 11.64 \\
\hline \multirow[t]{3}{*}{$\mathrm{H}$} & 3.05 & 5.00 & 5.00 & & 3.90 & 0.28 & -0.83 & \\
\hline & 3.17 & 4.76 & 4.76 & & 3.97 & 5.59 & 0.00 & -0.79 \\
\hline & 25.42 & 15.70 & 28.45 & & -6.54 & 13.22 & -2.92 & 3.55 \\
\hline \multirow[t]{3}{*}{$\mathrm{K}$} & 3.32 & 1.39 & -1.64 & -1.40 & & 0.00 & 2.48 & 0.00 \\
\hline & 4.79 & 3.19 & -0.01 & -0.81 & & -0.01 & 3.99 & 1.59 \\
\hline & 20.36 & 18.44 & 8.18 & 15.43 & & 5.40 & 6.54 & 0.54 \\
\hline \multirow[t]{3}{*}{$\mathrm{R}$} & 4.18 & 5.87 & 1.39 & 1.11 & -1.91 & & 4.18 & 1.11 \\
\hline & 3.99 & 5.59 & 1.59 & 0.79 & -0.01 & & 3.99 & 0.79 \\
\hline & 14.19 & 27.40 & 18.23 & 7.50 & 5.10 & & -8.80 & 9.21 \\
\hline \multirow[t]{3}{*}{$\mathrm{S}$} & 0.00 & 3.32 & -0.82 & 2.50 & -0.55 & 4.18 & & 4.14 \\
\hline & 0.01 & 3.16 & -0.78 & 2.38 & -0.78 & 3.99 & & 3.95 \\
\hline & 14.04 & 10.24 & 16.82 & 6.70 & 5.34 & -4.58 & & 2.86 \\
\hline \multirow[t]{3}{*}{$\mathrm{T}$} & -1.65 & -7.40 & -2.62 & 2.23 & 1.66 & 5.60 & -1.64 & \\
\hline & -1.57 & 0.78 & 0.01 & 2.38 & 1.58 & 5.59 & -1.57 & \\
\hline & 51.12 & 21.87 & 19.50 & 3.44 & 26.59 & 12.54 & -6.09 & \\
\hline
\end{tabular}

Note. For each crosses, first row: days to anthesis, second row: days to silking; third row: plant height; value with bold: best heterosis for each trait. 
Inbred lines in one group had a close resemblance relationship (Albrecht et al., 2010; Aguire \& Cabrera, 2012). The results of grouping were useful as a reference for determining the inbred lines as a pair of parent to produce hybrid. Parental pairwise which came from different groups or either with smallest similarity or greatest genetic distance potentially generated hybrids with high heterosis. Group III (C line) and Group II (B line) showed the lowest coefficient of similarity than other groups by i.e. $62.28 \%$ and $63.68 \%$, respectively.

In field corn, breeding for hybrid varieties is a well-recognized approach to yield increment through the heterosis exploitation. The role of genetically divergent germplasm is of primary importance for the phenomenon of heterosis to occur. Such phenomenon has been reported repeatedly where genetically unrelated parents will have better cross performance (Hallauer et al., 2010; Saleh et al., 2002).

The ability to provide similarity measures between the inbred lines that reflect pedigree relationship ensures a more stringent evaluation of the adequacy of morphological data. The fact that minimum similarity revealed between inbred lines with unrelated pedigree is a good indication conferring the ability of the two distance measures to distinguish between sweet corn inbred lines (Legesse et al., 2007). Morphological traits are useful for preliminary evaluation because they are fast, simple, and can be used as a general approach for assessing genetic diversity among morphologically distinguishable accessions (Yoseph et al., 2006).

The result of this experiment showed significant correlation between heterosis and genetic similarity in all the traits, except in the plant height. Morphological similarity with SCA showed highly significant correlation (negative) for the days to anthesis $(-0.67)$ and the days to silking $(-0.71)$, The positive correlation of SCA and genetic similarity in total solubled solids was 0.59 , indicating that the days to anthesis and the days to silking were in accordance with the theory of heterosis effect. While the positive correlation between similarity and heterosis/SCA was opposite to the heterosis established theory.

Table 6. Heterosis estimations of 56 hybrids for ear length, ear weight, and total solubled solids

\begin{tabular}{|c|c|c|c|c|c|c|c|c|}
\hline Hybrid & A & B & $\mathrm{C}$ & $\mathrm{H}$ & $\mathrm{K}$ & $\mathrm{R}$ & $\mathrm{S}$ & $\mathrm{T}$ \\
\hline \multirow[t]{3}{*}{$\mathrm{A}$} & & -0.29 & 15.14 & 15.74 & 18.56 & -9.95 & 11.31 & 14.68 \\
\hline & & 67.80 & 94.02 & 41.19 & 81.64 & 6.72 & 93.64 & 59.09 \\
\hline & & -19.69 & -3.05 & 17.17 & 13.92 & 1.42 & 9.60 & 8.35 \\
\hline \multirow[t]{3}{*}{$\mathrm{B}$} & 20.74 & & 15.65 & 7.27 & 0.50 & 12.28 & 18.26 & -5.72 \\
\hline & 110.19 & & 63.02 & 37.88 & 82.32 & 61.98 & 157.12 & 17.61 \\
\hline & 9.43 & & 3.21 & 0.14 & -5.03 & -5.80 & -9.08 & 10.47 \\
\hline \multirow[t]{3}{*}{$\mathrm{C}$} & 10.13 & 18.05 & & 12.30 & 15.48 & 11.31 & 19.38 & 1.65 \\
\hline & 72.82 & 70.94 & & 75.06 & 79.16 & 39.42 & 91.44 & 3.41 \\
\hline & 2.74 & -7.89 & & 11.88 & 8.38 & 9.14 & 10.13 & 2.28 \\
\hline \multirow[t]{3}{*}{$\mathrm{H}$} & 4.38 & 3.84 & 2.65 & & 0.74 & 8.06 & -3.90 & 11.55 \\
\hline & 18.28 & 54.22 & 21.52 & & 0.93 & 23.18 & -1.72 & 0.93 \\
\hline & 7.83 & -2.72 & 7.24 & & 11.06 & 33.70 & 7.83 & 6.79 \\
\hline \multirow[t]{3}{*}{ K } & 2.76 & 14.52 & -9.24 & 13.29 & & 5.74 & -2.53 & 30.40 \\
\hline & 63.21 & 107.86 & 37.56 & 45.84 & & 20.73 & 53.50 & 41.68 \\
\hline & 1.16 & -1.54 & 8.23 & 10.29 & & 2.24 & 5.49 & 3.94 \\
\hline \multirow[t]{3}{*}{$\mathrm{R}$} & 8.79 & 8.06 & 28.27 & 3.78 & -8.07 & & 17.98 & 21.41 \\
\hline & 52.64 & 62.24 & 75.20 & 11.23 & 2.23 & & 45.59 & 70.69 \\
\hline & 19.84 & 0.63 & 19.88 & 14.33 & 3.02 & & 20.94 & 19.11 \\
\hline \multirow[t]{3}{*}{$\mathrm{S}$} & 4.88 & 4.62 & 2.85 & -3.06 & 8.55 & 13.71 & & 5.08 \\
\hline & 80.30 & 97.51 & 59.95 & 27.83 & 56.66 & 37.39 & & 43.41 \\
\hline & 11.26 & -2.03 & 6.32 & 15.50 & 2.09 & 12.44 & & 8.74 \\
\hline \multirow[t]{3}{*}{$\mathrm{T}$} & 13.43 & 16.80 & 0.67 & 41.98 & 30.63 & 11.44 & 6.91 & \\
\hline & 55.80 & 50.95 & 26.27 & 59.20 & 80.57 & 56.92 & 29.81 & \\
\hline & 5.85 & -4.54 & -3.35 & 36.66 & 17.71 & 12.48 & 3.90 & \\
\hline
\end{tabular}

Note. For each crosses, first row: ear length, second row: ear weight; third row: total soluble solids; value with bold: best heterosis for each trait. 
Table 7. Estimates of genetic similarity (\%) based on morphological data for all pairwise combinations of eight sweet corn inbred lines

\begin{tabular}{llllllll}
\hline Inbred lines & $\mathrm{B}$ & $\mathrm{C}$ & $\mathrm{H}$ & $\mathrm{K}$ & $\mathrm{R}$ & $\mathrm{S}$ & $\mathrm{T}$ \\
\hline $\mathrm{A}$ & 63.68 & 62.28 & 71.51 & 82.04 & 70.74 & 70.64 & 71.51 \\
$\mathrm{~B}$ & & 62.28 & 63.68 & 63.68 & 63.68 & 63.68 & 63.68 \\
$\mathrm{C}$ & & & 62.28 & 62.28 & 62.28 & 62.28 & 62.28 \\
$\mathrm{H}$ & & & 63.68 & 70.74 & 70.64 & 75.86 \\
$\mathrm{~K}$ & & & & & 70.74 & 70.64 & 71.51 \\
$\mathrm{R}$ & & & & & 70.64 & 70.74 \\
$\mathrm{~S}$ & & & & & & 70.64 \\
\hline
\end{tabular}

Table 8. Pearson correlation coefficient of genetic similarity with specific combining ability (SCA) and heterosis for morphological traits

\begin{tabular}{lllllll}
\hline \multirow{2}{*}{ Parameters } & \multicolumn{6}{c}{ Morphological traits } \\
\cline { 2 - 6 } & DA & DS & PH & EL & EW & TSS \\
\hline SCA & $-0.67^{* *}$ & $-0.71^{* *}$ & 0.23 & 0.28 & 0.27 & $0.59^{* *}$ \\
Heterosis & $-0.68^{* *}$ & $-0.65^{* *}$ & 0.31 & $0.42^{*}$ & $0.68^{* *}$ & $0.41^{* *}$
\end{tabular}

Note. * and **: significant at P-value $\leq 0.05$ and P-value $\leq 0.01$, respectively; DA: days to anthesis; DS: days to silking; PH: plant height; EL: ear length; EW: ear weight; TSS: total soluble solids.

The correlation coefficients of morphological similarity with heterosis and SCA of agronomic traits were the most significant. It indicated that the similarity measures could be effective to predict the heterosis and SCA effects in the set of materials studied. Similar results were previously reported by Betran et al. (2003), a highly significant correlation $(\mathrm{r}=0.80)$ between genetic similarity and SCA effects in tropical maize inbreds grown under stress and non-stress environments. Melchinger (1999) and Betran et al. (2003) suggested that hybrid performance and heterosis can better be predicted when genetic similarity is smaller than a certain threshold, depending on the germplasm under consideration. Melchinger et al. (1990) noted that the level of correlations between genetic similarity to SCA and heterosis depend on the germplasm used.

In conclusion, the ear weight had the highest heterosis among all the traits studied, whereas negative heterosis was for days to anthesis and silking. The desirable heterosis for hybrids development was observed based on its ear weight and earliness of maturity. Either smaller genetic similarity or bigger genetic dissimilarity among all the inbred lines studied could be the indicators for bigger potency of heterosis, SCA and used for predicting hybrid performance of the days of anthesis and the days of silking. Otherwise, the total soluble solid showed positive correlation between genetic similarity and heterosis and SCA that probably expressed the additive genes control.

\section{Acknowledgements}

The authors would like to thank Agro Nusantara Prima, Ltd for allowing their collection of sweet corn inbred lines to be used in this study.

\section{References}

Aguirre, N. C., \& Cabrera, F. A. V. (2012). Evaluating the fruit production and quality of cherry tomato (Solanum lycopersicum var. cerasiforme). Rev. Fac. Nal. Agr. Medellin, 65(2), 6593-6604.

Albrecht, E., Escobar, M., \& Chetelat, R. T. (2010). Genetic diversity and population structure in the tomato-like nightshades Solanum lycopersicoides and S. sitiens. Annals of Botany, 105, 535-554. https://doi.org/ 10.1093/aob/mcq009

Assuncao, A., Madureira, B. E., de Oliveira, J. P., dos Santos, A. J. R., Pereira, A. P., Bueno, L. G., \& Ribeiro, R. M. (2010). Heterosis performance in industrial and yield components of sweet corn. Crop Breed Appl. Biotechnol., 10, 183-190. https://doi.org/10.1590/S1984-70332010000300001

Bered, F., Terra, T. F., Spellmeier, M., Barbosa, \& Neto, J. F. (2005). Genetic variation among and within sweet corn populations detected by RAPD and SSR markers. Crop Breed Appl. Biotechnol., 5, 418-425. https://doi.org/10.12702/1984-7033.v05n04a07 
Betran, F. J., Ribaut, J. M., Beck, D. L., \& de Leon, D. G. (2003). Genetic diversity, specific combining ability, and heterosis in tropical maize under stress and non stress environments. Crop Sci., 43, 797-806. https://doi.org/10.2135/cropsci2003.7970

Beyene, Y., Mugo, S., Gakunga, J., Karaya, H., Mutinda, C., Tefera, T., ... Tende, R. (2011). Combining ability of maize (Zea mays L.) inbred lines resistant to stem borers. Afr. J. Biotechnol, 10, 4759-4766.

Fehr, W. R. (1987). Principles of Cultivar Development. Theory and Technique (Vol. 1). Iowa, USA: Iowa State University Press.

Gerdes, J. T., \& Tracy, W. F. (1994). Diversity of historically important sweet corn inbreds as estimated by RFLP's, morphology, isozymes, and pedigree. Crop Sci., 34, 26-33. https://doi.org/10.2135/cropsci1994. 0011183X003400010004x

Hallauer, A. R., Carena, M. J., \& Miranda, F. J. B. (2010). Quantitative Genetics in Maize Breeding. Iowa, USA: Iowa State University Press.

Iriany, R. N. M., Sujiprihati, S., Syukur, M., Koswara, J., \& Yunus, M. (2011). Combining ability and heterosis of five sweet corn inbred lines (Zea mays var. saccharata) through diallel crosses. J. Agron. Indonesia, 39, 103-111.

Kashiani, P., Saleh, G., Abdullah, N. A. P., \& Abdullah, S. N. (2010). Variation and genetic studies in selected sweet corn inbred lines. Asian Journal of Crop Science, 2(2), 78-84. https://doi.org/10.3923/ajcs.2010.78.84

Kiula, B. A., Lyimo, N. G., \& Botha, A. M. (2008). Association between AFLP-based genetic distance and hybrid performance in tropical maize. Plant Breed, 127, 140-144. https://doi.org/10.1111/j.1439-0523. 2007.01434.x

Legesse, B. W., Myburg, A. A., Pixley, K. V., \& Botha, A. M. (2007). Genetic diversity of African maize inbred lines revealed by SSR markers. Hereditas, 144, 10-17. https://doi.org/10.1111/j.2006.0018-0661.01921.X

Legesse, B. W., Myburg, A. A., Pixley, K. V., Twumasi-afriye, S., \& Botha, A. M. (2008). Relationship between hybrid performance and AFLP based genetic distance in highland maize inbred lines. Euphytica, 162, 313-323. https://doi.org/10.1007/s10681-007-9503-6

Malik, S. I., Malik, H. N., Minhas, N. H., \& Munir, M. (2004). General and specific combining ability studies in maize diallel crosses. Int. J. Agric. \& Biol., 6, 856-859.

Marshall, S. W., \& Tracy, W. F. (2003). Sweet corn. In P. E. Ramstad, \& P. White (Eds.), Corn chemistry and technology (pp. 537-569). Minneapolis, USA.

Mattjik, A. A., \& Sumertajaya, I. M. (2011). Multivariate Analisys using SAS. Bogor, Indonesia: Institut Pertanian Bogor.

Mayo, O. (1987). The Theory of Plant Breeding (2nd ed.). New York, USA: Oxford University Press.

Melchinger, A. E. (1999). Genetic diversity and heterosis. In J. G. Coors, \& S. Pandey (Eds.), The genetics and exploitation of heterosis in crops (pp. 99-118). Madison, USA: ASA, CSS, and SSSA.

Melchinger, A. E., Lee, M., Lamkey, K. R., \& Woodman, W. L. (1990). Genetic diversity for restriction fragment length polymorphisms: relation to estimated genetic effects in maize inbreds. Crop Sci., 30, 1033-1040. https://doi.org/10.2135/cropsci1990.0011183X003000050016x

Ministry of Agriculture Republic of Indonesia. (2015). Sweet corn production in 2014. Retrieved April 13, 2014, from http://aplikasi.pertanian.go.id/bdsp/hasil_kom.asp

Nisya, F. N. (2010). Genetics variability of jathropa (Jatropha curcas L.) based on morphological traits and RAPD markers (MSc Thesis). Bogor, Indonesia: Institut Pertanian Bogor.

Olakojo, S. A., \& Olaoye, G. (2005). Combining ability for grain yield, agronomic traits and Striga lutea tolerance of maize hybrid under artificial striga infestation. Af. J. Biotechnol., 4, 984-988.

Revilla, P., Abuin, M. C., Malvar, R. A., Soengas, P., Ordas, B., \& Ordas, A. (2005). Genetic variation between Spanish and American version of sweet corn inbred lines. Plant Breed, 124, 468-271. https://doi.org/10.1111/j.1439-0523.2005.01091.x

Rifianto, A., Syukur, M., \& Trikoesoemaningtyas, W. (2013). Combining ability, yield, and yield component of seven sweet corn inbred lines across two locations. J. Agron. Indonesia, 41(3), 235-241. 
Saleh, G. B., Abdullah, D., \& Anuar, A. R. (2002). Performance, heterosis and heritability in selected tropical maize single, double, and three-way cross hybrids. J. Agric. Sci., 138, 21-28. https://oi.org/10.1017/ S0021859601001757

Suwarno, W. B., Pixley, K. V., Palacios-Rojas, N., Kaeppler, S. M., \& Babu, R. (2014). Formation of heterotic groups and understanding genetic effects in a provitamin A biofortied maize breeding program. Crop Science, 54, 14-24. https://doi.org/10.2135/cropsci2013.02.0096

Tracy, W. F., Whitt, S. R., \& Buckler, E. S. (2006). Sugary1 and the origin of sweet maize. Corp Sci., 46, 49-54.

Vasal, S. K., Srinivasan, G., Pandey, S., Cordova, H. S., Han, G. C., \& Gonzalez, F. (1992). Heterotic patterns of ninety-two white tropical CIMMYT maize lines. Maydica, 37, 259-270.

Yoseph, B., Botha, A. M., \& Myburg, A. A. (2006). Genetic diversity in traditional Ethiopian highland maize accessions assessed by AFLP markers and morphological traits. Biodivers Conserv., 15, 2655-2671. https://doi.org/10.1007/s10531-005-5407-8

Zhang, Y., Kang, M. S., \& Lamkey, K. R. (2005). Diallel-sas05: A comprehensive program for griffing’s and gardner-eberhart analyses. Agron. J., 97, 1097-1106. https://doi.org/10.2134/agronj2004.0260

\section{Copyrights}

Copyright for this article is retained by the author(s), with first publication rights granted to the journal.

This is an open-access article distributed under the terms and conditions of the Creative Commons Attribution license (http://creativecommons.org/licenses/by/4.0/). 